\title{
Lusotopie
}

Recherches politiques internationales sur les espaces

issus de l'histoire et de la colonisation portugaises

XVII(2)| 2018

Lusotopie. Concepts et pratiques

\section{Estado, riqueza e criminosos}

Nota introdutória por Michel Cahen e Isabel Raposo

État, richesse et criminels

State, Wealth and Criminals

\section{Christian Geffray}

\section{(2) OpenEdition}

\section{Journals}

\section{Edição electrónica}

URL: https://journals.openedition.org/lusotopie/3469

ISSN: 1768-3084

\section{Editora}

Idemec - UMR 7307

\section{Edição impressa}

Data de publição: 1 dezembro 2018

Paginação: 356-387

ISSN: 1257-0273

\section{Refêrencia eletrónica}

Christian Geffray, «Estado, riqueza e criminosos», Lusotopie [Online], XVII(2) | 2018, posto online no dia 01 julho 2021, consultado o 07 dezembro 2021. URL: http://journals.openedition.org/lusotopie/3469

Este documento foi criado de forma automática no dia 7 dezembro 2021.

Lusotopie 


\title{
Estado, riqueza e criminosos
}

\author{
Nota introdutória por Michel Cahen e Isabel Raposo \\ État, richesse et criminels \\ State, Wealth and Criminals
}

Christian Geffray

\section{NOTA DO EDITOR}

Tradução do artigo "État, richesse et criminels" publicado em Mondes en développement, CX (28), 2000: 15-30. Tradução de Isabel Raposo, revisão de Christine Messiant, Béatrice Hibou e João de Pina-Cabral. Uma edição em inglês foi publicada pela revista Lusotopie em 2002: Christian Geffray, "State, Wealth, and Criminals", Lusotopie, 2002, IX (1): 83-106, consultado 13 setembro 2018, https://www.persee.fr/doc/ luso_1257-0273_2002_num_9_1_1475.

Christian Geffray nos deixou uma obra vasta em livros, bem como dezenas de artigos publicados em revistas internacionais. Esta obra reflete uma forte interação entre uma fecunda e acutilante pesquisa de campo, assente em longas estadias sempre arriscadas, e a reflexão teórica continuamente alimentada pelo referido campo e estruturada por uma sólida formação filosófica e antropológica. Partindo de um marxismo crítico, sua constante preocupação em depreender as questões cruciais às sociedades periféricas que estudava determinou a escolha exigente dos seus objetos de investigação, levando-o a interrogar os conceitos da psicanálise para desenvolver o que chamou uma "antropologia analítica".

Seu primeiro trabalho de campo, um "clássico" da antropologia, no Norte de Moçambique, deu origem a Ni père, ni mère. Critique de la parenté: le cas makhuwa (1991, édition portugaise 2000). Neste livro, Geffray demonstra, contrariando a tradição estruturalista, que as palavras existentes para designar as relações de parentesco numa dada sociedade (macua) estão em perfeita concordância com a sua organização social. Um regresso ao mesmo campo, que se tornaria palco da 
violenta guerra civil que devastou esse país nos anos de 1980, permitir-lhe-ia entender as razões do prolongamento e do alastramento do conflito que não se esgotavam na política regional de desestabilização do apartheid. Em La cause des armes au Mozambique: Anthropologie d'une guerre civile (1990; edição portuguesa 1991), demonstra, pela primeira vez, a existência de causas internas e de uma base social de apoio à guerrilha, resultantes da política de modernização autoritária do Partido no poder, na altura de inspiração marxista-leninista, e da negação das relações sociais originais no seio do campesinato.

Seu novo campo, a Amazônia brasileira, e já na qualidade de pesquisador do Institut de recherche pour le développement (Paris), levou-o a abordar novos temas igualmente cruciais, como o papel social da morte para os índios, as situações fronteiriças e os espaços violentos onde se movem os garimpeiros, osmadeireiros e os narcotraficantes. Isto lhe permitiu desconstruir as relações de dominação paternalistas e os mecanismos da dívida imaginária que ligam os dependentes ao senhor (Maître). Assim sendo, codirigiu o dossiê "L'oppression paternaliste au Brésil", publicado no volume de 1996 da revista Lusotopie e publicou Chroniques de la servitude en Amazonie brésilienne (1995, edição portuguesa 2007). Um aprofundamento da reflexão teórica sobre a vida social, os ideais e o paternalismo, retomando suas pesquisas de campo e os conceitos psicanalíticos de Freud e Lacan, está na origem de Le Nom du Maître. Contribution à l'anthropologie analytique (1997). Parte novamente ao campo para mais uma pesquisa aprofundada na Amazônia, desta vez na trilha perigosa do narcotráfico; esta pesquisa dará origem a quatro empolgantes relatórios (1996-98) que foram publicados postumamente pela UNESCO, no quadro do programa Most sobre o narcotráfico que o próprio Geffray dirigiu (Geffray C. et ali. 2002). Foi este trabalho de campo que lhe serviu de referência para a sua reflexão crítica sobre o conceito de criminalização do Estado, defendida no artigo aqui apresentado.

Um outro tema, transversal as suas investigações anteriores, ocupará um lugar central nas reflexões de C. Geffray durante os seus dois últimos anos de vida: o que determina o valor dos bens na vida social. Estas reflexões serão apresentadas pela primeira vez num seminário no "Collège international de Philosophie" (1998-1999) e retomadas em Trésors. Anthropologie analytique de la valeur, livro concluído em setembro de 1999, mas cuja edição Geffray não testemunhará (2001). Neste trabalho, Geffray formula a tese de que os pares de categorias que procuram depreender uma tensão na vida social refletem, sempre, a distinção entre dois discursos (discurso entendido no sentido de laço social utilizado por Lacan): o "discurso do dom", voltado ao reconhecimento social, e o "discurso do mercado", concernente à provocação do desejo no outro, hoje dominante. Nesta sua incessante articulação entre a teoria e a realidade empírica, um novo campo se avizinhava, o de Ruanda, para a abordagem de outra questão igualmente crucial a nossa atualidade: o genocídio. Dele esperávamos novas contribuições decisivas para a análise da formação do laço social e da violência, da conceitualização do Estado e das instituições, da democracia e da cidadania. A morte, tão presente ao longo da sua pesquisa, tanto nos seus estudos de caso, quanto nas suas reflexões, chegou demasiado cedo, interrompendo este brilhante percurso. 
Esta é a primeira vez que o texto a seguir é publicado em português. Por se tratar de um artigo de considerável teor teórico, consideramos indispensável, após o aparecimento das suas versões francesa e inglesa, divulgá-lo em português, sobretudo porque o estudo de caso que ampara a sua reflexão teórica é brasileiro.

Michel Cahen e Isabel Raposo

\section{Referências}

Geffray, C. 1990, La cause des armes au Mozambique: Anthropologie d'une guerre civile, Paris, Karthala.

Geffray, C. 1991, A causa das armas. Antropologia da guerra contemporânea em Moçambique, Porto, Afrontamento.

Geffray, C. 1991, Ni père, ni mère. Critique de la parenté: le cas makhuwa Paris, Le Seuil. Geffray, C. 1995, Chroniques de la servitude en Amazonie brésilienne, Paris, Karthala, 1995.

Geffray, C. ed. 1996, “L'oppression paternaliste au Brésil”, Lusotopie, 3.

Geffray, C. 1997, Le Nom du Maître. Contribution à l'anthropologie analytique, Paris, Arcanes.

Geffray, C. 2000, Nem pai nem mãe. Crítica do parentesco: o caso macua, Lisboa, Caminho.

Geffray, C. 2001, Trésors. Anthropologie analytique de la valeur, Paris, Arcanes. Geffray, C., et ali. eds. 2002, Globalisation, drugs and criminalisation: Final research report on Brazil, China, India and Mexico, Paris, UNESCO [Vol. 1, Executive summary, drug trafficking and the state; Vol. 2, Drug trafficking, criminal organisations and money laundering; Vol. 3, Social and cultural dimensions of drug trafficking; Vol. 4, Methodological, institutional and policy dimensions of the research on drug trafficking]. Geffray, C. 2007, A opressão paternalista: cordialidade e brutalidade no cotidiano brasileiro, Educam-Editora universitária Candido Mendes.

Versão reduzida e reformulada do texto de homenagem a Christian Geffray, falecido aos 46 anos, em 6 de março 2000, redigido em 10 de março e publicado pela primeira vez no volume do ano 2000 de Lusotopie (Christine Messiant, Isabel Raposo e Michel Cahen, "Une grande tristesse. Christian Geffray nous a quittés", Lusotopie, VIII, 2001: i-iv). O volume de 2002 de Lusotopie apresentou uma biografia detalhada e comentada por Christine Messiant: "Christian Geffray: bibliographie et notes sur un parcours scientifique", Lusotopie IX (1), 2002: 6982, ou consultado em 3 de setembro de 2018, https://www.persee.fr/docAsPDF/

luso_1257-0273_2002_num_9_1_1474.pdf.

1 A corrupção dos funcionários e dos membros das mais altas instâncias de alguns Estados, por vezes o seu envolvimento directo em actividades criminosas, tem conduzido os observadores a utilizar expressões sugestivas como "Estado malfeitor", "narco-Estado", "Estado depredatório" ou "contrabandista", "Estado mafioso" e outras encarnações da noção mais genérica de "Estado criminoso". Os autores de La criminalisation de l'Etat en Afrique, por exemplo, descrevem de forma precisa e informada os fenómenos que justificam, a seus olhos, o uso destas noções inquietantes (Bayart, Ellis \& Hibou 1997); outros mostram como os representantes de certos Estados, em todos os continentes, abusam da sua autoridade para controlarem e organizarem, eles próprios, o tráfico ilegal de droga, de armas, de mão-de-obra ou o contrabando à escala 
dos seus países... A noção de "Estado criminoso" levanta contudo inúmeras questões, a começar pela identificação do verdadeiro autor do crime, do contrabando, do tráfico: será o próprio Estado ou não serão antes alguns dos seus representantes que abusam das suas funções no Estado tirando partido delas para traficar e fazer contrabando? Com efeito, a expressão "Estado criminoso" não é anódina; ela é mesmo grave e levanos a interrogar qual a relação que existe, por exemplo, entre os Estados apresentados como "traficantes", portanto "criminosos" e "malfeitores", e, por exemplo, o Estado nazi cuja qualificação criminosa enquanto Estado não levanta dúvidas a ninguém, tendo sido aliás julgado como tal em Nuremberga...

2 É certo que há traficantes que se instalam à cabeça de alguns Estados para violar as suas próprias leis apoiando-se nas funções que exercem em nome da lei, mas fará isto destes Estados, "Estados traficantes"? Fará esta expressão qualquer sentido enquanto o governo destes Estados não inclua um Ministério da Cocaína, com o nome gravado no frontão de um edifício oficial? Em definitivo, não será a fórmula "criminalização do Estado" senão o efeito de uma elisão realizada na locução mais completa: "criminalização da actividade de alguns representantes do Estado"? Se for este o caso, então deveremos admitir que esta elisão é tão frequente, ou mesmo sistemática, que não pode ser fortuita: ela revela talvez uma indefinição mais profunda que toca a natureza do Estado. Procuraremos levantar aqui algumas destas ambiguidades na definição do Estado e por consequência na definição da corrupção.

3 Evocaremos num primeiro tempo a situação de um deputado federal e traficante brasileiro, J.R., cujas actividades estudámos no trabalho de campo que realizámos entre 1995 e 1996 no Estado federal de Rondônia ${ }^{1}$. O deputado federal tornara-se notícia na crónica judiciária e jornalística de 1991 por ocasião da interpelação pela polícia em São Paulo de seu irmão encontrado na posse de $540 \mathrm{~kg}$ de cocaína. A notícia da sua prisão tinha provocado uma grande agitação em São João, a cidade dos R. ${ }^{2}$, tendo o presidente de câmara convocado precipitadamente o Conselho Municipal para organizar a "camuflagem" da fortuna do deputado antes da chegada à cidade dos polícias federais: os seus camiões foram expedidos para o Nordeste, milhares de cabeças de gado foram transferidas para os domínios de outros traficantes complacentes, etc. Para o que aqui nos interessa, retenhamos que os eleitos, também eles traficantes ou simples homens de confiança do deputado, não sentiram necessidade de se esconder; eles compunham os efectivos do Conselho Municipal e o mais simples a seus olhos era fazer a reunião, como habitualmente, no recinto oficial da câmara. Uma actividade criminosa foi assim planificada por alguns representantes locais do Estado brasileiro, no quadro de uma instância do Estado e intra-muros - uma ilustração entre tantas outras da dita "criminalização do Estado" que nós próprios procuramos entender: como é que foi possível uma tal reunião?

4 J.R. tinha sido em primeiro lugar um criminoso antes de se tornar posteriormente e simultaneamente representante do Estado e distinguiremos o seu caso dos representantes do Estado que seguem a trajectória inversa tornando-se posteriormente e simultaneamente criminosos: são por exemplo os funcionários ou eleitos que já não se satisfazem com o desvio dos fundos públicos e tiram partido do seu poder para ficar com a sua parte das actividades criminosas, colocando-as sob sua tutela ou envolvendose directamente nelas. Em ambos os casos, esforçar-nos-emos por compreender a utilização que uns e outros dão às suas riquezas ilegais na vida económica e social, local ou regional, em termos de consumo, de investimento ou de redistribuição das riquezas. 
Para apoiar esta reflexão, proporemos um modelo que permite pôr em evidência as duas maiores fontes de rendas ilegais - as actividades criminosas e o desvio dos fundos públicos - e a sua articulação com duas formas genéricas de corrupção: a neutralização e o abuso do poder do Estado. Por outro lado, seremos levados a distinguir e a opor duas formas não mercantis de circulação da riqueza: as partes por direito de cidadania e os manás clientelistas.

Por fim veremos, em conclusão, que a análise das formas de "criminalização do Estado" não pode prescindir de uma reflexão sobre o ideal de bem público que, em todos os tempos e lugares, comanda a legitimidade e a existência sociais da instituição estatal. Sendo o ideal por si próprio imutável, o que distingue as formas "moderna" e "patrimonial" do Estado não terá talvez tanto a ver com a letra das leis (mesmo que elas sejam "fundamentais") mas com o que é suposto garantir este ideal e estas leis no espírito das populações. Tal garantia não podendo ser, em última instância, senão do domínio da crença, a questão que no fundo nos preocupa é também talvez de saber onde reside a soberania nas crenças: no Povo, ou na figura de um qualquer Imperator, mesmo que ele esteja fora da lei? Contentar-nos-emos em colocar os termos do problema.

\section{Criminosos que se tornam representantes do Estado}

\subsection{J.R., traficante, ladrão e deputado federal}

6 No início dos anos 80, muito antes de se tornar deputado federal, J.R. tinha sido funcionário do Instituto da Reforma Agrária (INRA), encarregue da compra das colheitas da região recentemente colonizada. Ele convivia com os primeiros traficantes do Rondônia e, como eles, ocupava-se da compra em São Paulo dos produtos químicos indispensáveis ao fabrico do cloridrato de cocaína nos laboratórios bolivianos vizinhos. Familiar dos meios agrícolas e traficantes, muito cedo ele começou a desviar uma parte das colheitas que comprava por conta do Estado (arroz, café), para as exportar como contrabando para a Bolívia onde comerciantes as trocavam por cocaína. Rapidamente se tornou proprietário de numerosas empresas, se lançou na compra das colheitas de café, fundou uma empresa de exploração florestal, uma outra de transportes rodoviários, comprou uma balsa fluvial para explorar o ouro do rio Madeira, administrou concessões comerciais e tornou-se proprietário de numerosos bens imóveis em São João e outros lugares, de vários hotéis, de fazendas algumas equipadas com pistas aéreas, de aviões, etc... Quando, por volta do final dos anos 80, o acesso à cocaína por troca directa se popularizou, os fornecedores bolivianos passaram a aceitar todo o tipo de bens roubados ou importados do Brasil em contrabando: jóias, gado, ouro, cassiterite (minério de estanho), produtos agrícolas e sobretudo carros, camiões, maquinaria agrícola ou de construção civil, etc ${ }^{3}$. J.R. comanditou então um grupo de ladrões de veículos (camiões e automóveis destinados à troca directa com a cocaína boliviana) e mandou nomear um homem de confiança, como director do organismo estatal encarregue da matrícula dos veículos, o Ciretran, cujos funcionários legalizavam a documentação dos bens roubados por sua conta. De facto, a contrapartida em cocaína oferecida pelos bolivianos era maior se o camião ou o automóvel fossem fornecidos com os documentos em ordem ${ }^{4}$. 
Figura 1. Fonte e destino das rendas criminosas

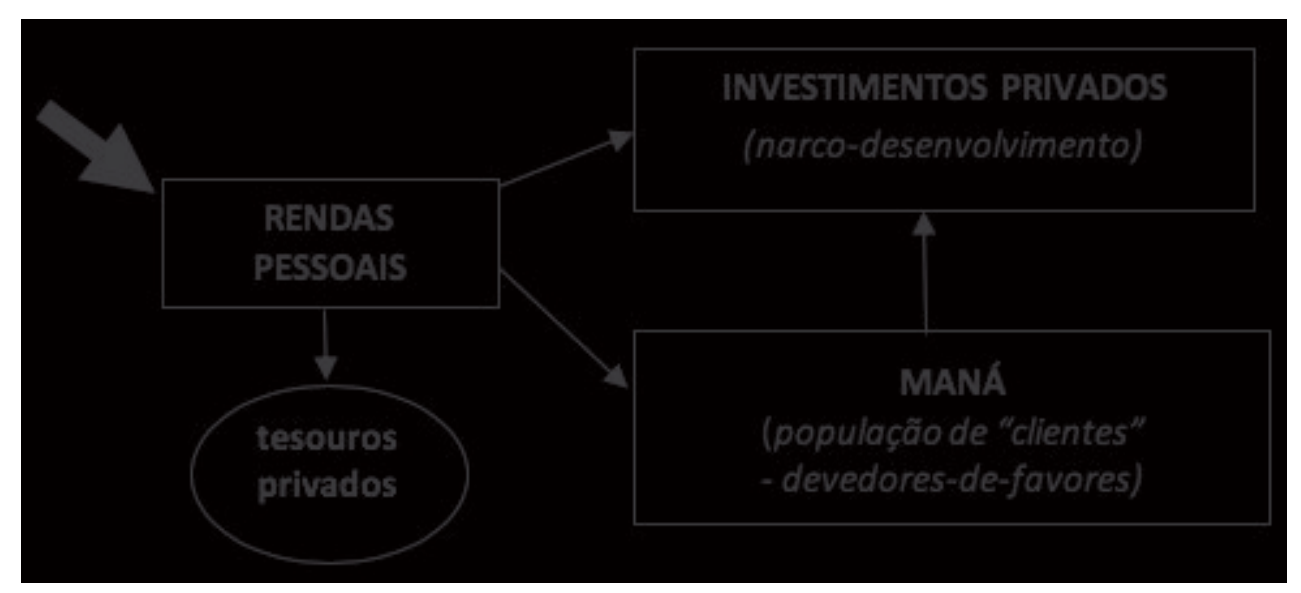

O traficante possuía uma balsa no rio equipada para a extracção do ouro, mas o nível de produção não era alto; ele contentava-se em comprar a bom preço o ouro apanhado pelos garimpeiros vizinhos, que depois revendia no mercado legal, declarando-o como fruto da sua própria produção; os garimpeiros escapavam assim ao imposto e vendiam o seu ouro acima do preço de mercado. Ele procedia do mesmo modo com a sua empresa florestal, cujos empregados declarados provavelmente nunca terão cortado o tronco de um mogno: ele comprava a madeira preciosa que era abatida clandestinamente, de noite, pelos madeireiros, nas regiões formalmente protegidas pelo Estado (Parques Nacionais ou Áreas Indígenas), permitia a esses picapaus o escoamento a bom preço da sua madeira preciosa fraudulenta, para depois a revender declarando-a como a produção da sua empresa...

Estas técnicas de branqueamento eram comuns na região e não distinguiam em nada J.R. dos seus pares traficantes, mas as suas operações ganharam nova amplitude com o café. Quando fundou a sua própria casa de compra do café, no início dos anos 80 , os seus recursos ilegais já lhe permitiam comprar o café acima do preço de mercado e revendêlo no exterior do Estado baixando os preços. Não dispondo os seus concorrentes dos mesmos recursos ilegais, alguns ficaram arruinados, outros reciclaram-se ou concentrarem-se no cacau, outros enfim foram comprados por J.R. (ou por um testa-deferro), de tal forma que em alguns anos este assumiu o controle do mercado regional do café, muito para além do seu município de São João. 0 conjunto da estrutura comercial do café foi completamente subvertido à escala do Rondônia onde o traficante acabou por usufruir, no limiar dos anos 90, de uma posição de monopólio. Notemos que sem a intervenção providencial de J.R., a cultura do café não teria provavelmente sobrevivido à concorrência do produto idêntico ("robusta") cultivado nas proximidades dos portos de exportação, a $3000 \mathrm{~km}$ do Rondônia, nas grandes plantações do Espírito Santo, já que comparativamente a produtividade era baixa no Rondônia e os camiões de J.R. levavam semanas a recolher os poucos sacos de café alinhados pelos pequenos colonos ao longo de milhares de kilómetros de picadas deterioradas pelas chuvas ...

9 O Estado não atribuía subvenções a este sector (café) e não lhe foram dirigidos quaisquer pedidos ou reclamações neste sentido de tal forma que nomeadamente os funcionários locais do Banco Mundial se admiravam com o que chamaram de "milagre do café do Rondônia". Eles pareciam ou queriam ignorar a causa profana do mistério, ou seja, que a produção do café do Estado do Rondônia, que fazia e continua a fazer o orgulho dos seus representantes políticos, era "subvencionada" de forma oculta pelo 
dinheiro da cocaína do deputado federal J.R.. Vendendo o seu café, dezenas de milhares de pequenos produtores tornavam-se na realidade beneficiários de um maná generosamente distribuído por J.R. e a génese da fortuna política e social do traficante reside nesta actividade económica legal, em que se tornou especialista no Estado, sem a qual não se compreenderia a estranha reunião do Conselho Municipal de São João.

\subsection{0 destino do dinheiro negro}

Uma riqueza vinda de fora inflectiu assim o curso da vida económica regional como se de uma subvenção se tratasse; contudo, aqui, ao contrário da subvenção, a riqueza não provinha do Tesouro Público mas de uma actividade criminosa e não era concedida em função de uma lei de distribuição legal do Estado mas de uma autoridade discricionária de um fora-da-lei; é por isto que preferimos qualificá-la de "maná" em vez de empregar as noções equívocas de subvenção "negra", "suja" ou "ilegal". Era aliás como tal que o dinheiro de J.R. se apresentava aos olhos dos garimpeiros, dos madeireiros, ou dos colonos de café, já que o seu detentor lhes comprava a um preço superior ao dos outros comerciantes; "maná" ainda, a oferta de créditos baratos ou gratuitos que o traficante tinha condições de prodigalizar aos empresários, fazendeiros e comerciantes locais em dificuldade ou a certos membros escolhidos das classes médias. Os seus favores eram sensíveis entre os membros de todos os estratos da sociedade local, não apenas entre os mais desfavorecidos, e qualquer um que o desejasse poderia chegar ao topo da cadeia dos bens ou serviços providenciais de que era devedor: acabaria por encontrar o nome deste homem que se entende que possa ter sido eleito cidadão de honra de São João (em 1997) - J.R., traficante de cocaína, ladrão e patrão de clientela. Comparando com as fortunas que ele distribuía, sob a forma de empréstimos ou de transacções mercantis que lhe eram voluntariamente desvantajosas, os presentes que ostensivamente oferecia (chocolates, brinquedos, bebidas e guloseimas distribuídas às crianças pobres no Natal e na Páscoa e outras manifestações de prodigalidade comuns na região) não representavam senão a encenação pública de uma audiência clientelista adquirida noutro lado, de forma obscura e muito mais substancial.

11 Uma vasta e forte corrente de cumplicidades directas, de conivências abertas, tácitas ou mesmo inconscientes, constituiu-se assim em torno do criminoso, envolvendo membros do conjunto da sociedade civil e de representantes locais do Estado, embora ninguém ignorasse o caracter ilegal, por vezes assassino, do seu cidadão de honra. Estas práticas redistributivas geraram finalmente a formação de uma bolsa de narco-desenvolvimento em torno do pólo de distribuição do maná resultante dos lucros ilegais do comércio da cocaína. Os beneficiários deste desenvolvimento eram todos, directa ou indirectamente, devedores do núcleo duro da clientela do deputado federal, verdadeiro promotor do "milagre" do café do Rondônia, como lhe chamavam os agentes do Banco Mundial, sensíveis à dimensão providencial do fenómeno... Enfim, a concessão do maná gerou uma nova diferenciação social entre as populações, pois alguns dos clientes-devedoresde-favores ${ }^{5}$ de J.R., contando-se entre os membros mais favorecidos da sociedade regional, conseguiram por sua vez conquistar uma posição vantajosa ou dominante no sector de activide legal em que intervinham, quebrando a concorrência graças ao maná concedido pelo traficante. Os mais poderosos comerciantes, concessionários de automóveis, companhias de taxi aéreo, agentes imobiliários, etc., podiam ser também dos maiores devedores-de-favores da clientela do traficante. Eles estavam em condições de assegurar, eles próprios e em seu próprio nome, a concessão de uma parte do maná 
proveniente do narcotráfico e de se promoverem assim como outros tantos sub-patrões de clientelas.

12 O circuito da riqueza aqui em causa poderia ser representado por um esquema, mostrando que as rendas pessoais ilegais ${ }^{6}$ resultantes do comércio da cocaína são susceptíveis de ser convertidas em três formas de riqueza distintas: a) em capital investido na economia legal (ou ilegal, antes de voltar sempre finalmente, branqueado, à economia legal); b) em maná posto em circulação sob a forma de presentes, ou de riqueza adicionada ao capital investido na economia legal: o maná tende então a romper com a concorrência e a polarizar o mercado; c) enfim, em tesouros privados, entesoirados ou consumidos pelos traficantes.

\subsection{0 maná}

13 A noção de "maná" tem contudo um uso demasiado raro em ciências sociais e a de "clientelismo" é talvez demasiado comum para que possamos prescindir aqui de algumas precisões. A palavra (maná) é habitualmente utilizada no vocabulario bíblico para designar uma riqueza de caracter providencial ("o alimento que Deus deixou cair do céu para as crianças de Israel no deserto" ") e foi retomada por A. Morice na análise dos processos económicos para qualificar a natureza da riqueza que circula nas redes clientelistas (Morice 1995: 50; 1999). Utilizado nesta accepção, o conceito apresenta várias vantagens analíticas: a) Permite tomar em conta o facto que os bens que entram na composição desta riqueza (o maná) não são postos em circulação a título de mercadorias, mesmo quando a riqueza muda de mãos por meio de uma transaç̧ão de forma mercantil, pois que não é o lucro que comanda a sua devolução: os comerciantes comuns, que vendessem ou comprassem aos preços praticados pelos que distribuem o maná entrariam rapidamente em falência. b) Ela permite também tomar em conta o facto que estas riquezas não são extraídas do Tesouro Público nem são distribuídas em virtude dum princípio legal de distribuição, mas resultam de uma actividade criminosa e são concedidas de acordo com o capricho ou a estratégia de um fora-da-lei, elas não são mercadorias nem tão pouco subvenções.

Esta forma de riqueza pode desconcertar os economistas, pois que se apresenta, na sua essência, como um favor distribuído a pessoas que provavelmente nunca estarão em condições de pagar tudo o que devem ao seu benfeitor. As riquezas assim distribuídas visam e geram a formação de uma dívida moralmente insolvente que as distingue das mercadorias, pois os comerciantes enquanto tais apenas se interessam pela solvência contabilística, e não moral, dos seus parceiros. Estas riquezas distinguem-se ainda dos bens oferecidos no quadro da instituição fundamentalmente igualitária do dom, já que a sua concessão não convida à reciprocidade, e apenas ganha o seu significado social pela impossibilidade em que se encontra o parceiro de pagar uma quantia equivalente. o dom, quando adquire figura institucional, supõe com efeito o pagamento das dívidas mútuas ou, mais precisamente, a renovação indefenida do endividamento recíproco que consagra a aliança de parceiros iguais (Godelier 1996: 54-60). É certo que os traficantes, como qualquer outra pessoa, podem dar neste sentido, quando procuram renovar ou alargar as suas alianças entre os seus pares ou outros patrões de clientelas, trocando serviços graciosos recíprocos, oferecendo e restituindo festas sumptuárias ... Mas o maná não suporta a reciprocidade e como tal, por meio destas festas, apenas atinge a clientela actual ou virtual dos convivas incapazes de restituir o seu convite. Ele assume, 
se se quizer, aos olhos dos seus beneficiários, o caracter de um dom sem reciprocidade, cujos efeitos sociais são logicamente inversos dos que resultariam da instituição do dom, já que eles são por natureza desiguais. A obrigação moral imposta ao beneficiário do maná de antecipar os desejos do seu benfeitor, não constitui uma figura da reciprocidade como por vezes se escreveu; pelo contrário, ela é o efeito subjectivo da incapacidade de restituir, de uma reciprocidade impossível que submete o beneficiário ao desejo daquele a quem fica $\mathrm{d}$ evedor-de-favores ${ }^{8}$, e que confere à riqueza concedida o seu carácter providencial. Esta formulação permite evitar os impasses a que na nossa opinião inevitavelmente conduz a análise do fenómeno em termos de "troca recíproca" de um bem "político" ou "social" por um bem "económico". Finalmente, notemos que a noção de maná permite muito simplesmente qualificar a riqueza envolvida em qualquer figura da dependência redistributiva, tal como esta foi evidenciada por K. Polanyi (1968) e vigorosamente formalizada por C. Meillassoux $(1960,1975)$, por exemplo. Ela poderia contribuir para a análise do laço social que estes autores souberam clarificar, permitindo considerar a sua estrutura subjectiva que nos preocupa e que pouco atraíu a sua atenção.

o patrão de clientela torna assim devedores-de-favores todos aqueles a quem oferece riquezas, já que estas tomam a seus olhos a forma de um favor que sabem que nunca poderão pagar e que nunca se lhes pedirá para pagar, desde que se mantenham fiéis (tal como os crentes não conseguirão pagar aos deuses o que crêem dever-lhes, seja qual for a dimensão dos sacrifícios que consintam para provar a sua fidelidade). As larguezas de J.R. não deviam nada nem às "leis" do mercado nem às do Estado, elas dependiam da solicitude e da disposição subjectiva do traficante, da sua generosidade ou do seu capricho. É neste sentido que elas revestiam, na nossa opinião, o caracter de um maná concedido a devedores-de-favores para quem o traficante encarnava, ipso facto, esta dupla figura da Providência et do Comendador comum a todos os pais imaginários e, como tal, ele era normalmente denominado, amado e temido por milhares de habitantes, modestos pioneiros, ou não, da região de São João: "É um pai para nós".

Saímos aqui do universo da mercadoria, para penetrar no coração do que fundamenta a legitimidade de uma autoridade que aliás não tem nada a ver com a lei legal: a legitimidade clientelista. Em torno dela estruturam-se redes de redes, ao mesmo tempo hierarquizadas e informais, profundamente opacas aos olhos dos que não lhes pertencem, mas capazes de pairar sobre a vida económica, social e política a tal ponto que por todo o lado aparecem a comandar a dinâmica e as orientações. "'Nós vivemos misteriosamente', confiava um zairense a J.-F. Bayart, para explicar a economia do seu país" e valorizar as suas exigências obscuras (Bayart 1997: 63). Potência inquietante com efeito, sendo verdade que pode resultar tanto de uma actividade legal como criminosa, cuja legitimidade é indiferente ao direito no seu princípio. Esta legitimidade surge irresistivelmente a partir do momento em que uma pessoa qualquer, independentemente de qualquer instituição, se encontra em condições de assumir simultaneamente e em seu próprio nome, a) a oferta providencial de favores a uma vizinhança que ela protege, $b$ ) a ameaça dos outros e o castigo dos beneficiários infiéis que traíssem a lei ideal que esta pessoa encarna para eles. Sabemos que as duas funções - concessão de favores e castigo, promessa de um bem e ameaça de um mal -, definem em definitivo o princípio de legitimidade de qualquer ordem social (elas distribuem-se geralmente numa composição de instituições múltiplas, judiciárias, religiosas, executivas, que fazem o encanto das cilvilizações)... Mas o patrão de clientela - é a sua definição - apresenta-se justamente como uma pessoa pronta a subverter qualquer 
edifício institucional, encarnando na sua própria pessoa essas funções universais. Procedendo deste modo, ele age como qualquer figura paternal e fica assim creditado, por aqueles que lhe ficam devedores-de-favores, da faculdade toda ela paternal, de dizer onde está o bem e o mal, mesmo que a sua palavra venha a contradizer as prescrições da lei legal... Esta capacidade de subverter quer o direito quer o mercado, especifica a natureza clientelista dos laços de obediência tecidos em torno da pessoa do patrão de clientela através da atribuição do seu maná, por oposição aos laços redistributivos legais que M. Weber, por exemplo, qualificava de "patrimoniais"(Weber 1995 [1956]: 285-349).

\subsection{A corrupção como neutralização do Estado}

17 Os laços clientelistas são indiferentes às prescrições da lei legal, mas apesar disso não eliminam os seus efeitos, tal como não afectam a existência social do Estado no verso do qual as clientelas crescem e se multiplicam. Estes laços podem ser imprevisível e indiferentemente legais ou ilegais, mas podem também constituir-se organicamente graças à subversão das leis, quando resultam da sua instrumentalização: quando as leis já não são mais do que "sinais a contornar, eixos em torno dos quais se inventam procedimentos para desenvolver novas relações", como escreveu B. Hibou (1997: 136). No caso que nos interessa dos traficantes de droga, em que os laços se tecem em torno de actividades criminosas que constituem uma violação e não uma subversão da lei, coloca-se aos traficantes o problema de se subtrair aos rigores da lei legal, por exemplo, neutralizando os que estão encarregues de a aplicar e de a fazer respeitar. Eles tomam então a iniciativa de corromper os representantes do Estado segundo um procedimento que vale para a neutralização de qualquer instituição: eles convidam um funcionário a renunciar a exercer o seu cargo contra eles, fazendo valer a) a promessa de um bem, de um serviço ou de uma riqueza particularmente desejáveis e providenciais, ou pelo contrário b) a ameaça de um mal terrível, incluindo a morte. Eles não pretendem aqui comprar "o poder" como é dito muitas vezes - senão eles gozariam desse poder de que se tornariam proprietários e exercê-lo-iam eles próprios, à maneira dos cargos venais do Antigo Regime. Também não compram "o funcionário" que, no sentido estrito, se tornaria seu escravo ... Eles compram ao funcionário um serviço preciso: a sua renúncia em exercer o seu cargo contra eles, embora continuando a ocupá-lo, pois que não lhes serviria de nada que ele se demitisse. 0 termo "traição" não é suficientemente forte para qualificar o comportamento dos representantes do Estado corrompidos, embora, como escreveu J. Cartier-Bresson (1998: 27, 1999: 68), o crime não lesione tanto as autoridades hierárquicas do funcionário quanto o próprio ideal de Estado que ele se comprometeu servir e que se situa para além da sua pessoa ou da dos seus superiores.

Seja qual for a sua forma, a corrupção supõe de facto a renegação pelo funcionário do compromisso subjectivo que ele é suposto ter contraído ao serviço dos ideais do Estado. Ela implica assim ao mesmo tempo a) uma renegação do ideal de bem público o qual legitima universalmente o exercício do poder de Estado, seja qual for a sua figura histórica, e consequentemente b) uma traição às populações que respeitam o Estado, tanto mais quanto a actividade do funcionário parece responder, aos olhos daquelas, às exigências de um tal ideal. Sublinhemos de passagem que a existência social do Estado não resulta da violência, mas antes da crença das populações, segundo a qual o exercício do poder do Estado procede de uma figura qualquer do ideal de bem público, a única na qual a sua legimidade se pode fundar... Trata-se aqui, na nossa opinião, de um facto 
antropológico que toca a natureza do Estado e não de uma opinião moral; um facto que se não fosse tomado em consideração na análise da corrupção tornaria o fenómeno incomprensível. Os efeitos morais da traição ao ideal do bem público são, como tais, efeitos sociais: do sucesso ou do fracasso da identificação aos ideais resulta a eclosão ou a fragmentação das crenças colectivas e portanto das instituições (muitas vezes na violência). A dimensão moral pertence à substância quer das práticas corruptivas quer do maná, o que explica talvez que as ciências sociais positivas experimentem algumas dificuldades em compreender o príncípio de uma como da outra.

19 Toda a legitimidade é do domínio da fé, o que os criminosos corruptores sabem bem, arranjando-se para que um funcionario tráia o ideal do Estado não tanto por cupidez, mas pela adesão ao ideal clientelista que eles representam (crença contra crença). Quando o conseguem, o seu dinheiro já não compra mais nada, pois assume a forma de um maná cuja atribuição transporta, na ordem simbólica, a conversão do funcionário seja qual for o vazio aparente do credo clientelista. A profissão de fé dos devedores-defavores de São João, por exemplo, funcionários ou não, é sempre redutível ao mesmo enunciado rudimentar: "eu acredito em J.R., é um homem forte e bom que me protege; ele viola a lei legal mas sabe onde se encontra o bem (a lei ideal) e devo servi-lo"... É certo que, em regra, aos criminosos pouco importam as crenças daqueles que eles corrompem: chega-lhes a cupidez dos funcionários como garantia da sua lealdade, desde que, para além da pessoa dos funcionários, os fora-da-lei consigam neutralizar os efeitos da lei legal. Se não conseguirem garantir esta lealdade nem pela adesão nem pela cupidez, então os criminosos sedutores tornam-se ameaçadores e prometem um mal. Eles ameaçam e matam:

Caro colega! Henrique. Fiel [?]. Esperávamos que respeitasses o nosso acordo. Sabes do que se trata! Não? Sabe-lo sim Henrique, esqueceste-te. Nós não. Tinhas prometido informar-nos de qualquer investigação a nosso respeito. A nossa grande sorte, é que tu tens um preço - muito baixo - tu não vales sequer um maço de cigarros. Lembras-te de nos teres ajudado nalgumas situações difíceis? Em que nós ganhávamos milhões e tu cêntimos? Henrique é de tal modo otário que nem sequer se apercebeu que estava a ser utilizado. Vendeu-se por: maços de cigarro, - $p$ equenas cervejas -, whisky e alguns litros de gasolina. Tu não és nada para nós, para a polícia, porque suspendes por um fio a vida dos teus colegas. Tudo isto te vai custar muito caro, a tua vida jaz porque não respeitaste o acordo 9 .

Um sujeito pode estar envolvido por fidelidade com diversos ideais, o Estado, os patrões de clientelas, a sua família, respondendo a exigências de credo eventualmente antagónicas, sempre que não lhe seja possível servir um sem trair o outro, tal como Antígona e Creonte. Estes credo, como qualquer crença, estão por outro lado expostos a uma subversão susceptível de os arruinar a todos em conjunto, pelo simples efeito da prática mercantil e da prevalência do interesse. Vislumbramos então a complexidade do universo moral em que se desenvolvem as estratégias sociais nas regiões de forte corrupção do Estado, portanto com forte audiência clientelista, em que se vive demasiado "misteriosamente". Fingir acreditar na palavra de uns e de outros ou calarse, dito de outro modo, respeitar ou interiorizar uma autocensura vigorosa, pode tornar-se uma exigência imperiosa da subsistência social ou mesmo fisica.

21 É evidente que, por seu lado, J.R., não acreditava no Estado, mas podia desejar que este se mantivesse estável, na integridade do seu organigrama, embora ficando sob o seu controle e estritamente paralizado no cumprimento das funções que o ameaçavam. 0 traço é provavelmente comum a todos os fora-da-lei: a sua existência social é parasitária em relação às populações no seio das quais eles prosperam como 
predadores, ela fica suspensa à existência da sociedade, onde as populações subsistem nas suas leis, e portanto, paradoxalmente, ao Estado que garantiu essas leis e que os fora-da-lei não imaginam sequer derrubar, mesmo quando os seus funcionários os incomodam ferozmente... De facto, os criminosos comportam-se em relação ao Estado no seu conjunto do mesmo modo que em relação a cada um dos seus representantes que eles corrompem individualmente: trata-se de fazer com que o Estado renuncie a exercer a sua função contra eles, embora continuando a ocupar o seu lugar. J.R. corrompeu e ameaçou, executou ou fez executar as suas ameaças a representantes do Estado; mas não tinha vantagem em discutir publicamente a legitimidade deste Estado fazendo política e, provavelmente, nunca imaginou servir um tal ideal (o que não poderia fazer sem contradizer o princípio do seu projecto clientelista); em contrapartida, a política serviu-o no seu empreendimento de neutralização do Estado, ao mesmo tempo que lhe permitiu potenciar o seu prestígio e audiência sociais.

Ele mobilizou os recursos da sua poderosa legitimidade clientelista para a valorizar no campo político legal, fazendo-se eleger na Câmara de Deputados da União. Ele próprio ocupou então um cargo público que lhe permitiu completar com vantagem a sua estratégia de neutralização do Estado e controlar, enquanto funcionário, as decisões e nomeações públicas úteis aos seus negócios, ao mesmo tempo que gozava da imunidade judiciária conferida pelo seu mandato parlamentar. Numerosos modestos eleitores chegaram mesmo a interpretar, paradoxalmente, o conjunto deste processo como uma forma de revitalização da autoridade e da legitimidade do Estado: ao fim e ao cabo, J.R. fazia coincidir a sua legitimidade clientelista com a legitimidade legal da representação popular no Estado. Ele encarnava a fusão dos dois ideais submetendo-se assim ao imperativo populista cuja divisa poderia enunciar-se em todo o lado como no Brasil "rouba mas faz", ou seja, "ele rouba mas faz alguma coisa", e dito de outro modo, ele viola a lei legal mas faz alguma coisa por nós, em conformidade com a lei ideal.

As estruturas locais do Estado foram sendo progressivamente esvaziadas da sua substância, alguns postos de comando estratégicos foram tomados pelos traficantes ou neutralizados pela corrupção ou a ameça de morte, mas isto não provocou reacção social, política ou judiciária particular: as populações pareciam viver em paz numa situação de relativa estabilidade social e política (havia comparativamente pouca delinquência em São João), e mesmo numa certa prosperidade económica. Os traficantes tinham conseguido legalmente os seus cargos no Conselho Municipal e, convencidos de um incontestável apoio popular, acreditavam, tal como os seus administrados, estar no seu lugar no recinto dos edifícios públicos. Entre as populações reinava, é certo, uma pesada censura aberta ou tácita no que respeita à informação sobre as actividades ocultas dos seus representantes - nem que mais não fosse para preservar o conforto de todos os que nada queriam saber do assunto... A prisão do irmão do deputado federal na posse de uma tonelada e meia de cocaína fez estilhaçar esta censura e pôs em perigo a pax traficana que vigorava em São João: compreendemos que ela tenha provocado a convocação de uma reunião excepcional do Conselho Municipal ${ }^{10}$. 
Corromper é a preocupação de todo o criminoso que se situa no exterior do Estado, a partir do momento em que se expõe à sua sanção e que se preocupa em escapar-lhe. Alguns, como J.R., estão em condições de resolver o problema instalando-se no interior do Estado: os criminosos tornam-se então, eles próprios, representantes do Estado e nada os impede de aumentar as suas rendas ilegais utilizando uma outra forma genérica de corrupção que lhes era até então inacessível: eles podem adicionar aos rendimentos do tráfico, os provenientes do desvio do bem público legalmente colocado ao seu alcance. $\mathrm{O}$ senador Olavo Pires, por exemplo ${ }^{11}$, cuja fortuna resultava tal como a de J.R. da importação-exportação da cocaína boliviana, desviava lotes de medicamentos e materiais sanitários do Ministério da Saúde para os distribuir gratuitamente no quadro da sua "Fundação Olavo Pires". Ele abusava do seu poder legal para converter um bem público em maná que distribuía em seu próprio nome, de tal forma que os produtos aos quais as pessoas tinham direito em virtude da sua simples cidadania, encontravam-se metamorfoseados em favores personalizados. As populações tornavam-se clientes devedores da pessoa do traficante-senador benfeitor; elas ficavam destituídas, ipso facto, da sua subjectividade cidadã igualitária. Estes desvios, comuns no Brasil e noutros lugares, eram independentes da actividade criminosa de O. Pires que agia aqui como simples senador corrompido e não como traficante: o criminoso tinhase tornado representante do Estado, e o seu comportamento não se distinguia por exemplo do do presidente angolano Eduardo dos Santos, que captava os fundos internacionais e as receitas não orçamentadas do país, como os fundos dos ministérios do seu governo, para distribuir a riqueza pública em nome da sua "Fundação Eduardo dos Santos" (Messiant 1999); a operação da conversão do bem público em maná personalizado é estritamente idêntica.

Esta evolução no termo da qual os fora-da-lei tais como J.R. ou Pires se podem tornar representantes do Estado não constitui senão uma das figuras da dita "criminalização do Estado". Vamos agora considerar a trajectória inversa no termo da qual os representantes do Estado se envolvem, directa ou indirectamente, em actividades criminosas.

\section{Representantes do Estado que se tornam criminosos}

\subsection{A corrupção como abuso do poder do Estado}

A forma de corrupção exercida por Pires com os medicamentos do Ministério da Saúde, ou por E. dos Santos para alimentar, também ele, uma fundação privada com o seu nome (e destinada a usar o seu nome), difere da que reteve até agora a nossa atenção. Já não se trata da neutralização do poder do Estado por um criminoso que lhe é exterior, mas do uso do poder do Estado por um dos seus funcionários para fins pessoais, que contradizem os fins ideais do Estado que ele se comprometeu servir: quer dizer, o abuso deste poder. Neutralização e abuso do poder apresentam-se, na nossa opinião, como duas modalidades genéricas de renegação dos ideais do Estado, facilmente diferenciáveis pela fonte das rendas ilegais que elas permitem acumular. Os criminosos exteriores ao Estado tiram os seus rendimentos de fontes independentes do Estado (tráficos, prostituição, roubo, etc.) e a corrupção apresenta-se para eles como uma operação para obviar à repressão; ela não permite, por ela própria, a captação de rendas, sendo 
mesmo onerosa para os que tomam esta iniciativa. Mas quando os funcionários tiram as rendas ilegais do Tesouro Publico (directamente, a montante ou a jusante do Tesouro, sob qualquer modalidade, em detrimento dos destinatários de direito da riqueza), então a corrupção é a própria operação de captação de rendas, ela dá lucro aos que tomam esta iniciativa. Perante a força da lei, digamos que há os que se situam no seu exterior e se dedicam a neutralizá-la e os que a cavalgam, esforçando-se por desviar os seus fins em proveito próprio.

Esta última operação permite qualificar um funcionário ou um eleito de corrupto, mas não é suficiente para o transformar num criminoso... Com efeito, não chega que os representantes do Estado abusem do seu poder e desviem os fundos públicos para que sigam a trajectória que nos interessa no termo da qual eles próprios se tornam criminosos. Com razão ou sem ela, o uso comum reserva esta qualificação para os que usufruem de rendimentos de actividades ilegais independentes das suas atribuições oficiais, tais como o roubo, o tráfico de estupefaciente, de prostitutas, etc ... Dito de outro modo, os funcionários, tornam-se criminosos no exercício das suas funções, quando abusam dos seus poderes, não para desviar fundos mas para colocar actividades criminosas sob sua tutela, com o fim de partilhar as rendas com os fora-da-lei, ou quando se envolvem directamente nelas, sem grande risco, a coberto das suas funções.

A colocação sob tutela das actividades criminosos - A colocação de criminosos sob a tutela de representantes do Estado prevaleceu muito tempo no México, por exemplo, e desenvolve-se em grande escala na China onde funcionários abusam colectivamente do seu poder, em redes, para impôr aos fora-da-lei o preço da sua própria neutralização enquanto representantes do Estado ${ }^{12}$. Luis Astorga interpreta este comportamento dos representantes do Estado como a cobrança de uma "taxa ilegal" (Astorga, 1998: 36), enquanto Jean Rivelois (1999: 280) o vê antes como a operação de um "racket legal"... "Racket branco" ou "imposto negro" são expressões que designam a situação de representantes do Estado que se consideram em condições de abusar dos seus poderes para impôr, eles próprios, o preço da sua renúncia em exercê-los. As duas formas genéricas de corrupção articulam-se intimamente neste dispositivo, onde o ganho com o abuso de poder se confunde com o desembolso consentido pelos criminosos para o neutralizar. É certo que o preço da corrupção é imposto pelos próprios representantes do Estado (abuso de poder), mas o conteúdo da transacção corruptiva permanece, por seu lado, idêntico (neutralização), já que os funcionários, uma vez pagos, renunciam a exercer o seu cargo embora continuando a ocupá-lo: eles auto-neutralizam-se ${ }^{13}$. Os representantes do Estado abrem assim o seu acesso às rendas de origem criminosa e as duas fontes de rendas ilegais (actividades criminosas e desvio de fundos públicos) confluem num reservatório virtualmente único, localizado sob a autoridade pessoal do corrupto criminoso. Elas podem então alimentar operações paradoxais, como esse governador de um Estado Federado mexicano, que tinha transferido o dinheiro recebido de narcotraficantes para as contas do seu Estado para oportunamente encher os cofres públicos. Quando os fluxos das duas rendas se tornam comunicantes, todos os circuitos passam a ser imagináveis, do financiamento da actividade criminosa com o imposto ao financiamento oportuno do Tesouro com o tráfico, ao sabor das exigências conjunturais do populismo. O populismo é afinal a lei que estrutura o campo político, sempre que a subsistência social das populações depende de redes clientelistas que se alimentam nos fundos de um Estado cuja direcção legal procede da eleição: a origem 
criminosa dos recursos distribuídos pelo governo, para usar o nome do governador, é indiferente.

Figura 2. Fontes e destino das rendas ilegais

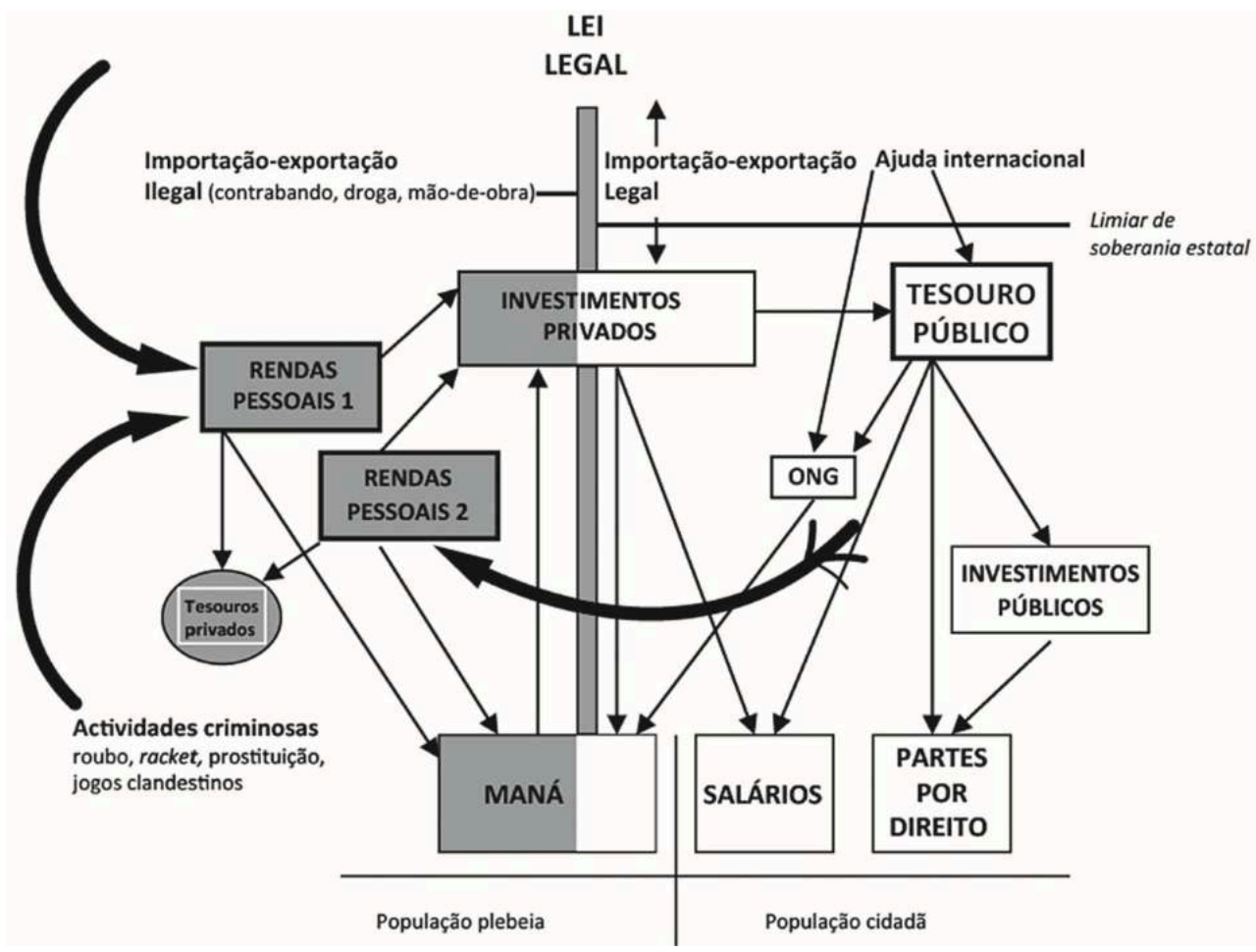

O envolvimento nas actividades criminosas. Algumas redes de representantes do Estado não se contentam com o controle das actividades criminosas e com a partilha dos ganhos. Os seus membros dão um passo suplementar quando exploram as prerrogativas das suas funções oficiais para realizar eles-próprios, directamente, uma operação criminosa. O deslize poderia ser ilustrado por um grupo de polícias civis de São João que fabricavam falsa cocaína à base de maizena, destinada à incineração legal em presença do juiz, enquanto vendiam a verdadeira cocaína por sua conta ${ }^{14}$. Estas práticas são naturalmente tanto mais preocupantes quanto mais centrais e elevadas na hierarquia do Estado são as funcções ocupadas pelos funcionários envolvidos, tal como esse Secretário de Estado do Interior e da Justiça do Rondônia, interceptado num laboratório boliviano em companhia de Olavo Pires enquanto negociava com traficantes ${ }^{15}$. Na Bolívia, justamente, o envolvimento de funcionários no narcotráfico foi durante muito tempo prática corrente de redes militares remontando até ao Estado Maior... Para além da América e do tráfico de estupefacientes, J.-F. Bayart menciona a existência de importantes redes de funcionários contrabandistas em outras actividades, na Gâmbia, no Togo, no Benim, na Guiné Equatorial, no Burundi, na Somália e nós poderíamos acrescentar na China (militares contrabandistas) ${ }^{16}$, ou lembrar o envolvimento de altas autoridades de alguns países africanos na cunhagem de moeda falsa, nos tráficos de exportação de mão-de-obra ou de prostitutas, de diamantes ou pedras semi-preciosas, de marfim ou de carnes e peles de animais selvagens, etc... (Bayard, Ellis \& Hibou 1997).

30 Esta criminalização das fontes de rendas ilegais de alguns representantes do Estado, leva a supor que os procedimentos clássicos do abuso do poder - o desvio de fundos no 
quadro do que J.-F. Bayart chama de "Estado cleptocrata" - já não são suficientes para a satisfação arrendatária das elites do sector público. As fontes tradicionais dos manás clientelistas acabam por se esgotar e numerosos autores situam este fenómeno na génese do alargamento contemporâneo do campo do abuso de poder, em que redes de funcionários decidem colocar sob o seu controle as actividades criminosas, ou dedicamse eles próprios directamente a elas, no quadro do que o mesmo autor qualifica de "Estado malfeitor" ${ }^{17}$. Com efeito, parece lógico supôr que o esgotamento das fontes das rendas estatais tradicionais provoque simultaneamente o aumento a) da audiência social de alguns criminosos fornecedores de maná (até lhes permitir a sua entrada no Estado) e b) da tentação, para alguns representantes do Estado, de captarem eles próprios essas riquezas criminosas (abusando do poder do Estado). Criminosos e funcionários são então susceptíveis de se aproximar, de se encontrar e de trabalhar juntos para este processo, embora a rivalidade no acesso às fontes de renda se agudize. A rivalidade atingirá o limiar de ruptura quando um grupo conseguir disputar militarmente, com as elites que controlam o Estado, o acesso às fontes de rendas. Um grupo armado poderá então subsistir, graças às punções que consiga exercer sobre as riquezas e ao eventual apoio de potências exteriores, comerciais ou políticas interessadas nas mesmas riquezas (ou animadas por outros fins)... Em todo o caso, dificilmente poderá subsistir na sedição, a não ser que legitime a sua intervenção no ideal através da invocação de uma qualquer nominação comunitarista. A etnia permanece um desses nomes, em África e em outros lugares (princípio de identificação colectiva), em virtude do qual uma fraç̧ão das populações de clientes privados de maná, pode tomar ou retomar a iniciativa para intervir na cena política estruturada pelo clientelismo.

Poderíamos completar o esquema da fig. 1 , juntando-lhe a fonte tradicional das rendas ilegais, a pilhagem do Tesouro Público pelos seus funcionários para alimentar as "rendas pessoais 2", independentes da actividade criminosa propriamente dita a qual compõe as "rendas pessoais 1" (tráficos nacionais e internacionais, roubo, racket, prostituição, etc.). Obteríamos assim uma imagem global dos fluxos das riquezas, das suas fontes e do seu destino, de cada um dos lados da lei legal:

\subsection{Comentário à fig. 2}

Todos os fluxos de riquezas que figuram na esfera legal neste esquema são susceptíveis de ser deslocados para alimentar as "rendas pessoais 2" na esfera ilegal, cada desvio constituindo uma das múltiplas figuras do abuso de poder (abuso de bens sociais, desvio de fundos, sobre-facturação ou sub-facturação de importação e de exportação, etc.). 0 destino das rendas "1" e "2" permanece idêntico embora as suas fontes difiram: elas são igualmente susceptíveis de ser convertidas em tesouros privados, em maná, ou reinvestidas na esfera mercantil legal onde são branqueadas. Em todos os casos, o maná adicionado aos capitais é igualmente capaz de polarizar uma diferenciação na economia legal beneficiando os grandes clientes a quem é concedido o maná, seja qual for a sua fonte. 

um dos lados da linha de demarcação constituída pela lei legal: de um lado, as rendas pessoais ilegais ( 1 e 2) e, do outro, o Tesouro Público, tal como é suposto ser administrado num Estado tecnicamente fiável aos olhos da comunidade internacional contemporânea em que se insere. A riqueza distribuída de cada um destes reservatórios reveste, por sua vez, duas formas distintas já que as riquezas que provêm legalmente do Tesouro não se assemelham aos manás concedidos na esfera ilegal. Aquelas apresentam-se sob a forma de partes atribuídas em virtude de uma lei legal de repartição escrita que não revestem o caracter de favores dispensados a beneficiários clientes- devedoresde-favores. Com efeito, sendo distribuído de acordo com a norma do Estado moderno, o bem público é composto por um conjunto de partes atribuídas por direito a cidadãos (que pagam impostos), capazes de se apoiarem na mesma lei legal para reinvidicar a sua quota parte na partilha: a atribuição da sua parte por direito ${ }^{18}$. Dito de outro modo, as riquezas que saem do Tesouro Público dos Estados contemporâneos, segundo a letra da lei ${ }^{19}$, não são favores creditáveis a uma pessoa que encarna a Providência, mas partes por direito creditáveis ao simples exercício da lei legal; não são portanto manás ${ }^{20}$.

Maná e parte por direito, estas duas formas de riqueza não mercantis, distribuídas em virtude de dois princípios distintos de repartição, instituem enfim populações cuja estrutura subjectiva é, também ela, radicalmente diferente, já que o povo dos cidadãos não é equivalente à população dependente dos clientes-devedores-de-favores. É certo que as duas populações não estão fisicamente separadas, no limite elas poderiam mesmo coincidir, o que não impediria de colocar a cada um a questão da sua identificação alternativa como cliente (plebeu) ou como cidadão do Estado. As condições de subsistência assentam então fortemente no que cada um crê ser, sobretudo no caso dos que não estão em condições de subsistir decentemente apenas com base no seu próprio salário (rendimento monetário legal) e nas suas partes por direito (abonos e serviços estatais legais, supondo que eles existem) e que dependem drasticamente dos manás (abonos e serviços clientelistas personalizados, legais ou ilegais)...

Notaremos que as três formas de riqueza distribuídas à massa da população, o maná, o salário legal e as partes por direito, correspondem às três componentes da remuneração real do trabalho que A. Morice distinguiu nomeadamente no setor de obras públicas no Brasil (Morice 1999: 114). O autor interpreta a insuficiência notória dos rendimentos legais (salários e partes por direito) como um fenómeno estrutural que torna indispensável a concessão suplementar de favores à mercê dos empregadores, condição da mobilização paternalista da mão-de-obra. Sem ser necessariamente ilegal, o maná patronal não é reconhecido, ele entra no domínio do que vulgarmente se chama "informal".

\section{Estado moderno como crença}

Reflectimos até ao momento, como se de alguma forma fosse evidente que o Tesouro Público fosse pilhado pelos que dele são responsáveis e o administram em nome do ideal do Estado. Como se a lei legal e a constituição escritas dos Estados estivessem desligadas de qualquer lei ideal e que, por consequência, grosso modo, ninguém acreditasse nelas: nem nos ideais proclamados do Estado nem no destino legal do Tesouro Público. Como se fosse evidente que a fé colectiva que alimenta a legitimidade

Lusotopie, XVII(2) | 2018 
das autoridades públicas não pudesse proceder na realidade, fosse qual fosse a configuração jurídica dos Estados e o discurso dos seus representantes, senão da concessão dos manás que circulam, diante do Estado e da letra da lei, nas clientelas polarizadas por personagens poderosas, amadas ou temidas pela multidão obscura ou colorida dos seus clientes-devedores-de-favores. Como se por seu lado, estas personagens tivessem empenhado a sua carreira no Estado não para aí servir os seus ideais, mas porque o controle dos cargos estatais se apresentava como uma exigência estratégica de acesso às rendas convertíveis em tesouros privados, em capital e em maná. Enfim, como se o controle do Estado, apresentasse como único interesse o de ser uma condição desta promoção clientelista, de forma que os patrões de clientelas, sem abdicar do bem público, reinterpretavam de tal modo o ideal do Estado que votavam irresistivelmente à subversão populista, a sua versão oficial proclamada, com o consentimento partilhado e por vezes apaixonado das populações. Finalmente não nos interrogámos sobre o facto desta versão oficial do bem comum, publicamente reinvindicada como ideal pelos representantes do Estado e portanto reputada comandar a existência social do Estado, estar em todo o lado condicionada pela figura internacional dominante do Estado dito "de Direito", onde a riqueza comum está submetida a uma lei de partilha legal.

Como conceber este desfasamento entre as leis do Estado e as práticas clientelistas, se admitirmos que não se pode reduzir a referência ao Estado de Direito ao efeito de um novo "condicionalismo" da ajuda internacional, a uma simples figura da dependência mundial do Ocidente? Não menosprezamos a existência de uma aspiração democrática das populações ao direito, que vai para além da falsificação populista estrutural da sua expressão pública; também não ignoramos a profundidade das expectativas depositadas no recurso à autoridade das leis legais, tanto mais preocupantes quanto a multiplicidade destas aspirações não as torna menos impotentes para reter a lei quando ela se escapa ... É um dos aspectos do sofrimento social e político nos países dependentes e, justamente por esta razão, importaria compreender o que é que leva ao declínio de toda a ancoragem simbólica das leis legais no ideal. o que é que faz com que nenhum ponto de direito ${ }^{21}$ consiga fazer lei e ser aplicado na plenitude do seu princípio (salvo relação de forças conjuntural), e que uma modificação do direito não altere nada porque, como nota B. Hibou, "o princípio director dos comportamentos consiste justamente em contornar e em não fazer caso das regras" (Hibou 1997: 136)? Como se estas compusessem uma espécie de tela imaginária nas malhas da qual conviesse entrançar incansavelmente as ligações clientelistas em que se estabelece a verdadeira subsistência social, com o risco de as refazer indefinidamente à medida das perturbações que afectam a trama das leis legais. A tela é imaginária, isto também quer dizer que ela pretende enganar, mas a quem? Aos doadores? Às populações que desejam ainda e decididamente, contra tudo e contra todos, acreditar na existência social do direito? Aos corajosos que denunciam a subversão das leis e completamente sós vêm bater com a cabeça na parede simbólica da lei, enquanto os patrões de clientela e a sua comitiva a atravessam quais fantasmas?

Poderíamos colocar o problema de um modo completamente diferente, com o risco de dar às nossas questões um tom mais provocante. Se é verdade que a lei moderna é impotente para garantir que seja exercida de acordo com o seu princípio, então porque é que as populações e os que as dominam não podem usufruir, em vez dela, de um dispositivo legal conforme à lei ideal clientelista, na qual manifestamente acreditam e 
que de facto mobiliza a sua fé? Afinal de contas, o Estado suportou durante muito tempo que as riquezas do seu Tesouro fossem cedidas sob a forma de maná: este princípio de repartição caracterizou mesmo a circulação do bem público desde a sua génese, há seis mil anos ... Da Suméria às últimas monarquias (não constitucionais), o maná foi sempre redistribuído como tal e legalmente no espaço do Estado ${ }^{22}$; o bem público procedia então inevitavelmente da pessoa de um qualquer Imperator, garante do Tesouro e chefe institucional de um povo de clientes-devedores-de-favores legais: os seus sujeitos. A pessoa do rei era ela própria uma instituição (contrariamente ao patrão de clientela) que era escrita em tábuas de lei: o Rei Soberano encarnava legalmente para os seus súbditos a dupla figura da Providência e do Comendador, conforme a uma lei ideal cujos enunciados eram desenvolvidos no registo da religião, porque a matriz do direito era sempre, então, de ordem divina. Era o Estado "patrimonial" de Max Weber, cujas formas de sujeição parecem coincidir em muitos aspectos, é verdade, com as do clientelismo, a tal ponto que J.-F. Médard qualificou as figuras contemporâneas deste útlimo como "neo-patrimoniais" (Médard 1998: 55-67)... Notemos contudo que as práticas clientelistas não procedem do cumprimento das leis legais pois que elas lhes são indiferentes e exercem-se quer na sua subversão quer na sua violação. Neste sentido, as práticas a-legais do clientelismo parecem-nos dificilmente assimiláveis à legalidade patrimonial e para resolver a dificuldade talvez não seja suficiente considerar, como parece sugerir J.-F. Médard, que o clientelismo seja uma espécie de patrimonialismo fora-da-lei e o patrimonialismo uma forma de clientelismo legal. $\mathrm{Na}$ nossa opinião, não é anódino que o maná seja distribuído dentro ou fora-da-lei: na realização das instituições ou na precipitação da sua falência. A distinção parece discriminante e não é certo que a sua nomeação graças ao uso do sufixo "neo" (patrimonialismo) seja suficiente para dar conta do que separa as duas configurações sociais.

39 A questão um pouco ousada que colocámos acima, poderia aliás ser formulada em termos weberianos: porque é que o patrimonialismo se tornou hoje impossível, tão inacessível às populações que retêm a nossa atenção quanto o Estado de Direito? O presidente Eduardo dos Santos não parece contudo tão longe do patrimonialismo em Angola: ele disfruta ainda da legitimidade do chefe de partido único revolucionário e antiimperialista, forjado nos antigos combates marxistas-leninistas do MPLA; disfruta igualmente, desde há menos tempo, da legitimidade democrática do vencedor das eleições de sufrágio universal, apesar do massacre dos adversários perpetrado nos dias que seguiram a proclamação do resultado dos votos; enfim, ele progrediu para uma forma de institucionalização da sua legitimidade clientelista graças à sua Fundação $\mathrm{E}$. dos Santos, que, como se viu, permite converter nomeadamente os fundos públicos em maná presidencial personalizado ... Contudo, a despeito da acumulação imponente destas legitimidades encaixadas, apesar da força política e da aura carismática que daí resultam para o chefe de Estado, este, verosimilmente, nunca conseguirá disfrutar do cumprimento institucional do princípio clientelista da sua autoridade: ele nunca será consagrado Rei de Angola e provavelmente ele próprio, como qualquer outro homem de Estado prepotente mas sensato, em África ou em outro lugar, não o sonha (os que pensaram nisso e o concretizaram, na África Central, deixaram o sentimento de uma trágica bufonaria, montada com o consentimento da antiga tutela colonial)...

40 Estes chefes de Estado não se podem tornar reis, sem dúvida pelas mesmas razões que impedem os procedimentos patrimonialistas, exercendo-se de facto, de se escrever e se proclamar de jure, ou as leis escritas e proclamadas do Estado de Direito de se inscrever 
e se exercer de facto segundo o seu princípio. Não arriscaremos uma discussão que nos conduziria demasiado longe dos nossos propósitos e competências, mas podemos pelo menos lembrar, em conclusão, o conteúdo da crença muito particular, que se situa no princípio do que se chama o Estado de Direito. É a este Estado-ideal que parecem aspirar os membros de tantas populações sem que acreditem nele colectivamente para elas próprias, enquanto que, como Ideal do Estado, o Estado de Direito é já hoje suposto comandar a existência social da maioria das suas instituições públicas (em quase todo o lado na América Latina, num grande número de países de África e da Ásia).

O Estado moderno (como as outras formas de Estado) é com efeito uma instituição, cuja existência social está suspensa a uma crença (como as outras instituições) susceptível de ser confortada ou abjurada como qualquer outra crença... Esta crença serve um ideal imutável para lá da variedade de figuras históricas do Estado: trata-se sempre e sómente do bem público. O ideal não permite pois especificar, por ele próprio, as crenças colectivas associadas às diversas formas de Estado. $O$ que distingue as crenças tem sobretudo a ver com o que vem garantir este ideal aos olhos das populações e que constitui o objecto próprio das suas crenças, graças às quais o Estado prevalece e existe socialmente de acordo com o seu princípio ou não. No Estado patrimonial, para retomar a tipologia weberiana, as coisas eram bastante simples já que a pessoa de um Imperator garantia o bem público assim como o Tesouro de onde tirava o maná destinado aos seus súbditos. Todos eram devedores dos seus favores e responsáveis perante ele das suas faltas a uma lei ideal que ele encarnava na sua pessoa. Como o rei era apesar de tudo um sujeito real, isto é, falível no seu corpo e na sua palavra, o que em verdade ninguém ignorava, um qualquer sujeito fictício de natureza divina (ou a sua vontade) era suposto encarnar-se nele ou representar-se nele, ou tendia-se a crer que o Imperator era ele próprio como tal do domínio do divino (todos os reis, não apenas os antigos de Inglaterra, possuíam de algum modo "dois corpos") (Kantorowicz 1991 [1957]). Estes sujeitos fictícios constituíam o objecto próprio da crença, derradeira, em que se fundava a legitimidade e a existência social dos Estados.

Mas o Tesouro do Estado moderno não é um maná. Ele é distribuído de acordo com uma lei de repartição legal desencarnada, em que os cidadãos se podem apoiar para reivindicar a atribuição da sua parte do bem comum; esta parte não se apresenta para eles como um favor mas como um direito. Para instituir na história este tipo de Tesouros de onde nenhum maná procede foi geralmente necessário cortar a cabeça dos Imperatores que os guardavam e garantiam, tendo-se o cuidado de não meter nenhum outro no lugar e p odemo-nos interrogar sobre o que veio garantir, aos olhos de todos, esta espécie de lei de repartição e este tipo de Tesouro. Com efeito, já não havia Rei e o Estado, por ele próprio, qualquer que fosse a "racionalidade" da sua administração, não podia garantir uma lei em que os cidadãos se podiam formalmente apoiar contra ele ${ }^{23}$. Que se passou, depois de decapitados os Imperatores, enquanto nenhuma ordem divina vinha mais seriamente garantir o bem público ao qual, houvesse o que houvesse, os novos representantes do Estado deviam continuar a ordenar a sua acção? O que veio em lugar da cabeça cortada do Rei Soberano, já não era um princípio divino mas o Povo Soberano. Este povo tem apenas uma existência simbólica, não tendo portanto uma existência mais real que os deuses ou o "segundo corpo do rei": é um sujeito fictício, como eles objecto de crença, mas a legitimidade do Estado moderno ordenou-se a esta crença. Sujeito fictício, garante do ideal do Estado, o Povo Soberano é igualmente uma fiç̧ão sagrada que se encarna como tal, por exemplo, nos juris populares ou nas contagens eleitorais (estes procedimentos, por eles próprios perfeitamente irracionais, 
são reputados acabar com a recorrência de uma dúvida sobre a culpabilidade de um acusado ou sobre a orientação dos desejos que tocam o bem comum: ali onde o Rei decidia, o Povo decide.). Deus ou Povo, os sujeitos fictícios são afinal o objecto de todas e quaisquer crenças que venham garantir a lei no espírito dos homens: eles sacralizam tudo o que tocam ${ }^{24}$... Contudo, a ficção do Povo soberano não é de natureza comparável à que se encarnava nos Reis soberanos. Em verdade, a crença e o seu objecto, a nova ficção, já não são aqui religiosas mas políticas; o Povo soberano é mesmo a ficção em que se funda muito precisamente, desde que nisso se acredite, a possibilidade da política como tal. Esta crença tende então a subverter todas as outras, já que ela proibe toda a encarnação da lei ideal e arruina de antemão toda a legitimidade dos Imperatores: já não há lugar aqui, contando que uma pessoa consiga deslizar para aí por roubo, senão para a figura grega do tirano provido das qualidades demagógicas e clientelistas capazes de lhe assegurarem o triunfo populista.

43 A repartição do Tesouro sob a forma de partes por direito é um princípio de distribuição simples, tão evidente quanto "racional" em aparência; mas, para se aplicar na realidade, de acordo com a sua norma, ele supõe igualmente que seja garantido a montante pelo sucesso de uma operação colectiva a qual se realiza na ordem simbólica. No caso presente, o funcionamento do Tesouro Público moderno supõe a existência desta crença colectiva particular, segundo a qual o soberano é o Povo e não um qualquer Imperator que lhe quisesse bem; segundo a qual o pagamento dos impostos é um acto cívico de participação na soberania mais do que o reconhecimento de uma fidelidade; segundo a qual a colectividade se institui como fraternal, contando-se os seus membros como tantos pequenos mestres livres participando numa soberania comum e independente de qualquer encarnação paternal da lei (ao que se chama, algo curiosamente, de "indivíduos"), etc.

Ninguém ignora contudo que uma crença não se decreta e aí reside seguramente a dificuldade, o nó sensível de toda a questão, e nomeadamente para os investigadores. Podemos admitir que o Estado de Direito seja o nome de um Ideal do Estado (simbólico) e de um Estado ideal (imaginário), portanto, no limite, tanto uma questão de luta social e política quanto uma realidade institucional. Mas temos de admitir também que as populações que crêem neste ideal para elas próprias, tirando ao mesmo tempo partido desta crença diante dos outros e para os outros - dito de outra forma, as populações aos olhos das quais o Estado de Direito é a instituição de uma lei ideal garantida pelo Povo Soberano no qual acreditam -, são hoje ainda as populações dos Estados donos do mundo. É sobre a interpretação deste fenómeno que se articulam as teses culturalistas susceptíveis de orientar a reflexão para os terrenos mais escorregadiços, ou mesmo perigosos; e é sobre a denegação do mesmo fenómeno que se fundam os comentários mais convencionais e lenitivos, formulados em nome de organismos obrigados, por função é certo, a uma forma de ingenuidade (instituições diplomáticas, políticas ou económicas internacionais, imprensa). Entre os dois, os investigadores têm a sua responsabilidade. 


\section{BIBLIOGRAFIA}

Andrieu, J. 1996, “Chine: une économie communautarisée, un État décomposé”, Revue Tiers Monde, XXXVII (147): 659-687.

Astorga, L. 1998, Drug trafficking in Mexico, relatório do 2eminário anual MOSTUNESCO, Rio de Janeiro (dactilografado).

Bayart, J.-F. 1997, “Le 'capital social' de l'État malfaiteur, ou les ruses de l'intelligence politique", in Bayart, Ellis \& Hibou eds., La criminalisation de l'État en Afrique, Paris, Complexe: 55-76.

Bayart, J.-F., Ellis, S. \& Hibou, B. eds. 1997, La criminalisation de l'État en Afrique, Paris, Complexe.

Cartier-Bresson, J. 1998, “Les analyses économiques des causes et des conséquences de la corruption : quelques enseignements pour les PED”, Mondes en Développement, 26: 25-40.

Cartier-Bresson, J. 1999, “Causes et conséquences de la délinquance financière 'grise' : le cas de la corruption", Les Cahiers de la Sécurité Intérieure, 36: 63-90.

Fabre, G. 2000, Décentralisation, corruption et criminalisation : la Chine dans une perspective comparative, seminário MOST-IRD, Paris (dactilografado).

Geffray, C. 1998, Effets sociaux, économiques et politiques de la pénétration du narcotrafic en Amazonie brésilienne, Rapport d'activité, no2, 3, 4, Mato Grosso-Rondônia, IRD-CNPq (dactilografado).

Godelier, M. 1996, L'énigme du don, Paris, Fayard.

Hibou, Béatrice 1997, “Le 'capital social' de l'État falsificateur, ou les ruses de l'intelligence économique”, in Bayart, Ellis \& Hibou eds., La criminalisation de l'État en Afrique, Paris, Complexe: 105-158.

Joxe, A. 1991, Voyage aux sources de la guerre, Paris, PUF.

Kantorowicz, E. 1991 [1957], Les Deux corps du Roi, Paris, Gallimard.

Littré, É. 1958, Dictionnaire de la langue française, Paris.

Médard, J.-F. 1998, “La crise de l'État néo-patrimoniale et l'évolution de la corruption en Afrique sub-saharienne”, Mondes en Développement, 26: 55-67.

Meillassoux, C. 1960, "Essai d'interprétation du phénomène économique dans les sociétés traditionnelles d'autosubsistance", Cahiers d'Études Africaines, 4: 38-67.

Meillassoux, C. 1975, Femmes, Greniers et Capitaux, Paris, Maspéro.

Messiant, C. 1999, “La fondation Eduardo dos Santos (FESA). À propos de l'investissement' de la société civile par le pouvoir angolais", Politique Africaine, 73: 82-101.

Morice, A. 1995, “Corruption, loi et société: quelques propositions”, Revue Tiers Monde, XXXVI (141): 41-65.

Morice, A. 1999, "Recherches sur le paternalisme et le clientélisme contemporain : méthodes et interprétation", mémoire pour l'habilitation à diriger des recherches, Paris, EHESS (dactilografado).

Polanyi, K. 1968, Primitive, Archaic and Modern Economics, New York, Doubleday.

Rivelois, J. 1999, "Drogue, corruption et métamorphoses politiques (applications à une comparaison Mexique-Brésil)”, Revue Tiers Monde, XL (158): 271-296. 
Safouan, M. 1993, La parole ou la mort, Paris, Le Seuil.

Weber, M. 1995 [1956], Économie et société. 1. Les catégories de la sociologie, Paris, Plon.

\section{NOTAS}

1. As informações que apresentamos são na sua maioria inéditas, retiradas da documentação disponível nos aquivos da Superintendência da Polícia Federal de Porto Velho, Rondônia (relatórios de investigações policiais, processos verbais de interrogatórios e peças do processo do irmão do deputado) e confrontadas com outras fontes (entrevistas, imprensa, outras fontes de arquivo administrativas, policiais e judiciais), durante o trabalho de campo realizado entre Outubro de 1995 e Agosto de 1996 no Mato Grosso e no Rondônia. Ver Christian Geffray, Rapport d'activité, $n^{0}$ 4, Trafic international, blanchiment local et politique (Abril-Agosto 1996) (in Geffray 1998). 2. O nome da família e o da cidade foram substituídos por pseudónimos.

3. Dizia-se que o domínio de Yayo Rodriguez, um dos principais fornecedores bolivianos de cocaína da região, "parecia um parque de estacionamento". Um semi-reboque Volvo, Scania ou Mercedes podia ser trocado por $70 \mathrm{~kg}$ de cocaína na Bolívia, que podiam ser revendidos por cerca de um milhão de dólares US na costa Altântica e por cerca de sete milhões no mercado europeu. 0 camião apenas havia custado, ao comanditário da operação, o salário dos homens de mão.

4. Estas práticas tinham-se espalhado por todos os Estados federados brasileiros que fazem fronteira com a Bolívia e estimularam o roubo de veículos (entre outras riquezas) no conjunto da União Federal. A circulação de uma grande quantidade de bens roubados era assim reorientada e drenada de ladrão para receptador, de receptador para traficante, de São Paulo, Rio de Janeiro, Espírito Santo, Salvador da Bahia, Brasília, Belém, etc., até aos fornecedores bolivianos de cocaína próximos da fronteira brasileira do Mato Grosso, do Rondônia, do Acre. Para evitar que fosse dado o alerta antes do veículo atravessar a fronteira, os motoristas podiam ser mortos. Sérios problemas de segurança afectaram o conjunto da rede viária dos Estados fronteiriços, onde já não se circulava mais de noite no virar dos anos 90 .

5. NT: traduzimos obligé por "devedor-de-favores" ou nalguns casos por "cliente- devedor-defavores".

6. O termo "renda" designa os rendimentos da actividade illégal.

7. "La nourriture que Dieu fit tomber du ciel pour les enfants d'Israël dans le désert" (Littré 1958: 1963).

8. NT: em vez de uma tradução mais literal de qui l'oblige, "que o obriga", optámos por esta fórmula, "a quem fica devedor-de-favores" que nos remete para a tradução de obligé como indicado na nota 7.

9. Esta mensagem foi encontrada numa gaveta de um comissariado da polícia civil de São João pelos agentes da Polícia Federal em 1991. Ela tinha sido enviada alguns meses antes pelos polícias traficantes a um tal Henrique. Ignoramos se estes polícias estavam ligados a J.R. (documentação da Polícia Federal de Porto Velho, processo A. R.). N.T: Não dispondo do texto original em brasileiro, apresentamos aqui a tradução para português da versão francesa desta mensagem.

10. Apenas retivémos de São João o caso do deputado federal J.R., sem dúvida o mais importante traficante da municipalidade e o único que se envolveu tão longe e espectacularmente nas conquistas dos cargos do Estado; a este título ele pareceu-nos exemplar. O nosso propósito não deve contudo induzir em erro, a família J.R. não era a única que controlava o tráfico em São João onde agiam, tal como nas outras municipalidades do Rondônia, várias redes de traficantes, independentemente umas das outras, preocupadas em manter um respeito mútuo elementar, garante da sua discreção. Estudámos o caso de pelo menos dois outros grandes traficantes operando em São João (sem contar com os que trabalhavam na comercialização ocasional de 
alguns kilogramas de cocaína). Estes homens investiam localmente no comércio urbano ou no gado bovino, mas não estabeleciam qualquer relação com a economia regional do café e permaneciam discretamente à margem da vida pública e política e portanto de J.R. Este último, perdeu o seu mandato federal na sequência da prisão do seu irmão, mas não foi possível condenálo directamente.

11. Amigo de J.R. e como ele grande traficante, O. Pires ter-se-ia provavelmente tornado governador do Rondônia se não tivesse sido assassinado na véspera da sua eleição.

12. Ver Andrieu (1996). Guilhem Fabre (2000) desenvolve uma crítica conjunta das aborda-gens culturalistas (J. Andrieu) e funcionalistas (J.-L. Rocca) da corrupção chinesa, numa perspectiva comparável à nossa.

13. Isto supõe uma relação de forças histórica particular entre o Estado e os criminosos; os casos mexicano e chinês permitem pensar que o fenómeno não é estranho à existência de uma autoridade partidária única e poderosa sobre o Estado. Pelo contrário, no Brasil, só a nível da pequena distribuição urbana é que os funcionários corrompidos se podem constituir em banda para "taxar" sistematicamente os traficantes; mais acima na hierarquia, são os traficantes que impõem aos funcionários o preço da corrupção. Um oficial da polícia militar do Mato Grosso apelidado o "Rambo", julgando-se suficientemente forte para impor aos traficantes o preço do seu silêncio (200 000 US\$ para fechar os olhos a uma transacção), foi metralhado com a sua família em Rondônopolis, em 1995, quando desenvolvíamos o nosso trabalho de campo no local.

14. Eles coagiam un antigo "químico", familiar dos laboratórios bolivianos, a fabricar o pro-duto, ameaçando-o de prisão sob a pressão de um dossier falso. Este sacrificava um kilograma de verdadeira cocaína para obter cerca de dez kilogramas de maizena que reagia positivamente aos testes de cobalto., Christian, Geffray 1998 op. cit., pp. 87-91, Porto Velho, Fórum de Justiça, processo 188/94.

15. Christian Geffray, op. cit., pp. 106-108, Porto Velho, Fórum de Justiça, processo M. A. da Silva Souza, fl. 638-640.

16. “... na província do Guandong, em 1994, os orgãos de segurança da polícia armada e todas as suas unidades subordinadas foram intimadas a 'cessar de gerir ou de adquirir participações em diversos lugares de recreio, incluindo saunas, salões de massagem e cabeleireiros'. A inspecção geral do Ministério da Segurança tomou as mesmas disposições ao nível nacional para acabar com o desenvolvimento de 'clubes de recreio e de casinos, que prosperavam graças aos seus laços com a polícia local', sustentados por antigos reclusos, comprometendo a campanha contra a criminalidade", China Daily, 18 de Outubro, 1994, citado por G. Fabre (2000: 14).

17. Contudo, fazer do próprio Estado o autor da "malfeitoria" (méfait) permanece, do nosso ponto de vista, abusivo: também neste caso, não existe um Estado cunhador de moeda falsa, enquanto não for oficialmente inaugurado um Anexo dos Ministérios de Finanças consagrado à impressão $\mathrm{e}$ à administração da moeda falsa. Neste sentido, o Estado cleptocrata também não existe: apenas existem redes de funcionários detentores de certos cargos no Estado que abusam deles para roubar ou imprimir moeda falsa.

18. NT: "parte por direito", tradução literal de part de droit.

19. NT: "letra da lei", tradução literal de lettre des lois.

20. Contrariamente ao que sugere a expressão infeliz "Estado Providência". Os fundos públi-cos distribuídos às associações tendem a revestir o caracter de um maná legal (não ilegal), sempre que as ONG nacionais se apresentam como os novos operadores institucionais, extra-estatais, do clientelismo de Estado.

21. NT: optámos aqui igualmente por uma tradução literal de point de droit.

22. Lembremos que o Estado, no sentido em que aqui o invocamos, nasceu há seis mil anos em torno da administração de estabelecimentos ou entrepostos que abrigavam tesouros com vocação pública - reservas alimentares no caso - e esses bens públicos foram fortificados, segundo A. Joxe, 
antes de se edificar a muralha das cidades e de se inventar o exército permanente de soldados especializados e as guerras de impérios (Joxe 1991: 91-99).

23. A Razão garantiu eventualmente o ideal da administração, mas não o bem público, seja o que for que disto pensem, no seu racionalismo ingénuo, os altos funcionários mais dedicados e Max Weber....

24. Ver Moustapha Safouan (1993: 57-58). O autor desenvolve uma concepção analítica ins-pirada em Lacan que nós retomamos aqui, que postula a invenção de um sujeito fictício nomeado (nome da lei) ao mesmo tempo "inútil e necessário" para garantir o simples exercício da função simbólica (lei do nome).

\section{RESUMOS}

Apresenta-se uma reflexão sobre a criminalização das atividades dos representantes dos Estados, que resulta de um estudo de casos (o narcotráfico num Estado da Amazônia brasileira). Distinguese duas fontes de rendas ilegais - as atividades criminais e o desfalque de fundos ou serviços públicos -, cuja captação supõe o recurso com dois princípios genéricos de corrupção, a neutralização e o abuso de poder do Estado. Devem ser distinguidas duas formas não mercantis de colocação em circulação da riqueza: os manás dos clientes (legais ou ilegais) e as quotas de direito de cidadãos. A reflexão sobre o Estado e a sua corrupção não parece por ser levado de forma satisfatória, a não ser que se percebe (como para qualquer instituição) de que forma é garantido o ideal que comenda e legitima a sua existência social. Tratando-se do Estado, este ideal é o bem público.

Cette étude présente une réflexion sur la criminalisation des activités des représentants des États, introduite par les résultats d'une étude de cas (le narcotrafic dans un État d'Amazonie brésilienne). Sont distinguées deux sources de rentes illégales - les activités criminelles et le détournement de fonds ou services publics-, dont la captation suppose le recours à deux principes génériques de corruption, la neutralisation et l'abus du pouvoir d'État. Deux formes non marchandes de mise en circulation de la richesse doivent être distinguées: les mannes clientélistes (légales ou illégales) et les parts de droit citoyennes. La réflexion sur l'État et sa corruption ne paraît pas pouvoir être menée de façon satisfaisante, à moins de comprendre (comme pour n'importe quelle institution) comment est garanti l'idéal qui commande et légitime son existence sociale. S'agissant de l'État, cet idéal est le bien public.

We present a reflexion on the criminalization of activities of State representatives, introduced by the results of a case study (drug trafficking in a Brazilian Amazonian State). We shall distinguish two sources of illegal income - criminal activities and the misappropriation of public funds or misuse of public services -, the collection of which assumes recourse to two generic corruption principles, neutralization and the abuse of State power. Two non-trade forms of putting wealth into circulation must be distinguished: clientelist manna (legal or illegal) and legal reallocation of financial resources to the citizens. Reflection on the State and its corruption cannot, in our opinion, be conducted satisfactorily without understanding (as for any institution) how the ideal which controls and legitimises its social existence is guaranteed. As regards the State, this ideal is the public good. 
ÍNDICE

Mots-clés: bien public, clientélisme, criminalisation, mannes, état

Palavras-chave: bem público, clientelismo, criminalização, Estado, manás

Keywords: public good, clientelism, criminalization, manna, State

\section{AUTOR}

\section{CHRISTIAN GEFFRAY}

Institut de recherche pour le développement, Centre d'études africaines, École des hautes études en sciences sociales, Paris, France 